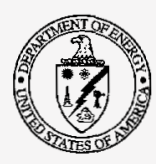

U.S. Department of Energy

\section{RECEIVED}

\section{JUN 021998}

\section{INSIDE $\mathrm{S} \mathrm{T} \mathrm{I}$}

Solar Control

Window Energy
Rating and Labeling

Window Checklist

Window Energy

Glossary

\title{
Selecting Windows for Energy Efficiency
}

New window technologies have increased energy benefits and comfort, and have provided more practical options for consumers. This selection guide will help homeowners, architects, and builders take advantage of the expanding window market. The guide contains three sections: an explanation of energy-related window characteristics, a discussion of window energy performance ratings, and a convenient checklist for window selection.

electing the right window for
a specific home invariably
requires tradeoffs between different energy performance features, and with other non-energy issues. An understanding of some basic energy concepts is therefore essential to choosing appropriate windows and skylights. As illustrated on the following page, three major types of energy flow occur through windows: (1) non-solar heat losses and gains in the form of conduction, convection, and radiation; (2) solar heat gains in the form of radiation; and (3) airflow, both intentional (ventilation) and

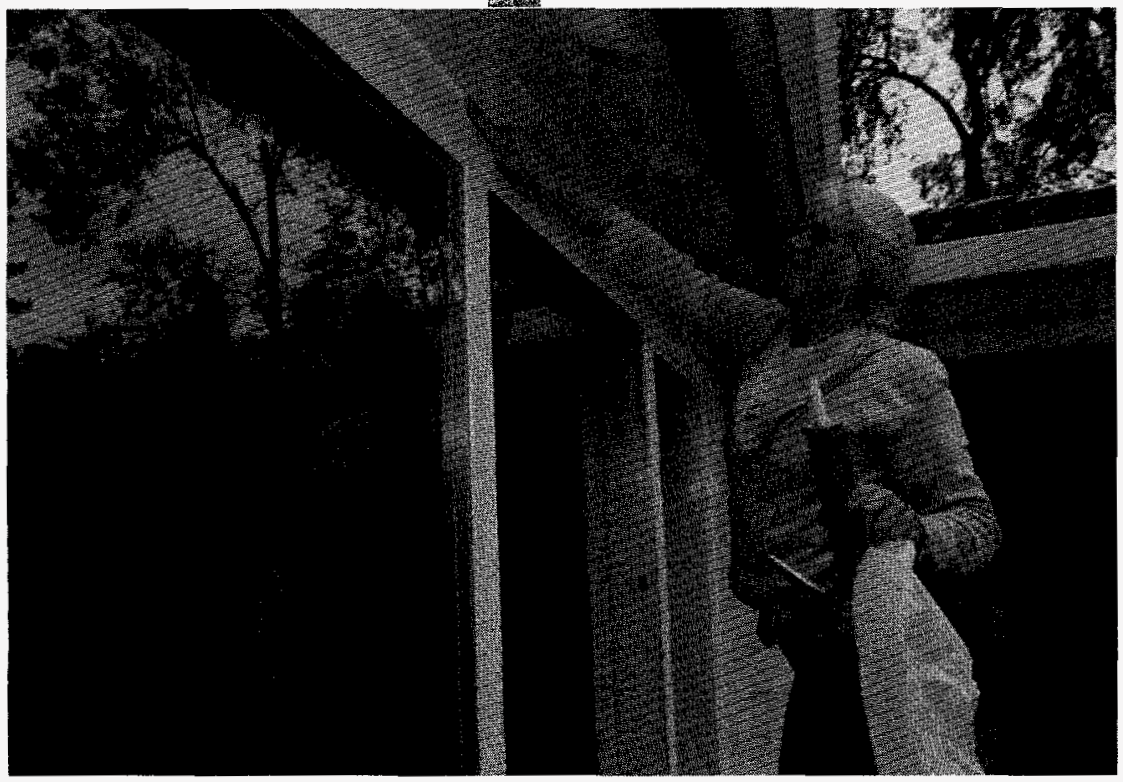

unintentional (infiltration). (See the Window Energy Glossary for explanations of these terms.)

\section{Insulating Value}

The non-solar heat flow through a window is a result of the temperature difference between the indoors and outdoors. Windows lose heat to the outside during the heating season and gain heat from the outside during the cooling season, adding to the energy needs in a home. The effects of nonsolar heat flow are generally greater on heating needs than on cooling needs because indoor-outdoor temperature differences are greater during the heating season than during the cooling season in most regions of the United States. For any window product, the greater the temperature difference from inside to out, the greater the rate of heat flow. of non-solar heat flow through a window or skylight. (An R-value is a measure of the resistance of a window or skylight to heat flow and is the reciprocal of a $U$-factor.) Lower $\mathrm{U}$-factors (or higher $\mathbf{R}$ values), thus indicate reduced heat flow. U-factors allow consumers to compare the insulating properties of different windows and skylights.

The insulating value of a singlepane window is due mainly to the 
The three major types of energy flow that occur through windows: (1) nonsolar heat losses and gains in the form of conduction, convection, and radiation; (2) solar heat gains in the form of radiation; and (3) airflow, both intentional (ventilation) and unintentional (infiltration).

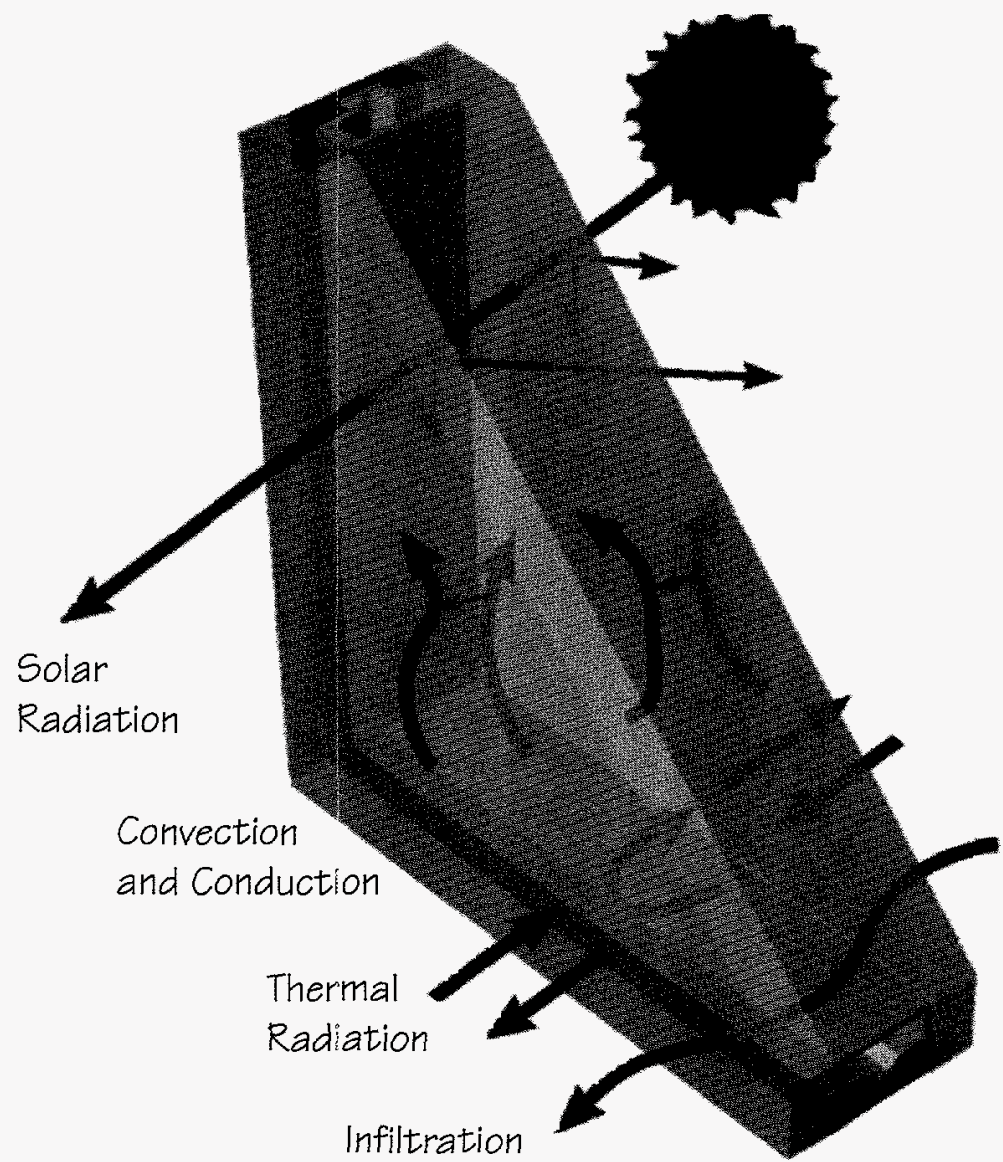

thin films of still air on the interior and moving air on the exterior glazing surfaces. The glazing itself doesn't offer much resistance to heat flow. Additional panes markedly reduce the $U$-factor by creating still air spaces, which increase insulating value.

In addition to conventional double-pane windows, many manufacturers offer windows that incorporate relatively new tech-

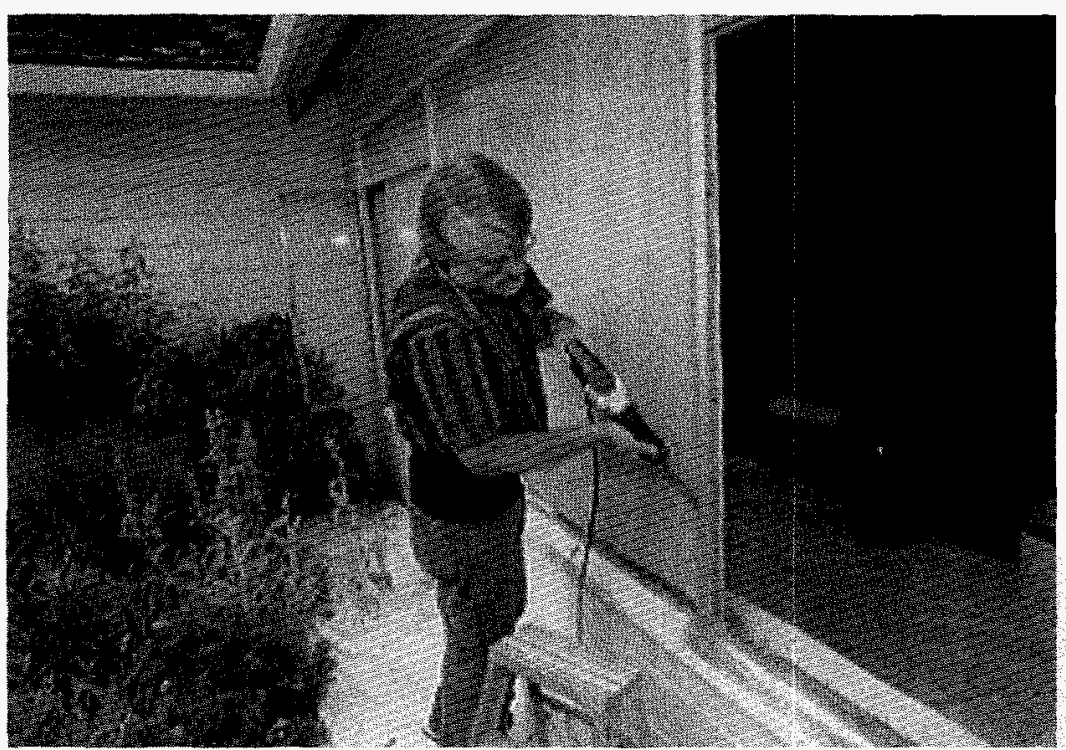

nologies aimed at decreasing $\mathrm{U}$-factors. These technologies include low-emittance (low-E) coatings and gas fills.

A low-E coating is a microscopically thin, virtually invisible, metal or metallic oxide coating deposited on a glazing surface. The coating may be applied to one or more of the glazing surfaces facing an air space in a multiple-pane window, or to a thin plastic film inserted between panes. The coating limits radiative heat flow between panes by reflecting heat back into the home during cold weather and back to the outdoors during warm weather. This effect increases the insulating value of the window. Most window manufacturers now offer windows and skylights with low-E coatings.

The spaces between windowpanes can be filled with gases that insulate better than air. Argon, krypton, sulfur hexafluoride, and carbon dioxide are among the

High-performance windows make energyefficient homes possible with greater freedom of design than in the past. 


\section{DISCLAIMER}

This report was prepared as an account of work sponsored by an agency of the United States Government. Neither the United States Government nor any agency thereof, nor any of their employees, make any warranty, express or implied, or assumes any legal liability or responsibility for the accuracy, completeness, or usefulness of any information, apparatus, product, or process disclosed, or represents that its use would not infringe privately owned rights. Reference herein to any specific commercial product, process, or service by trade name, trademark, manufacturer, or otherwise does not necessarily constitute or imply its endorsement, recommendation, or favoring by the United States Government or any agency thereof. The views and opinions of authors expressed herein do not necessarily state or reflect those of the United States Government or any agency thereof. 


\section{DISCLAIMER}

Portions of this document may be illegible in electronic image products. Images are produced from the best available original document. 
gases used for this purpose. Gas fills add only a few dollars to the prices of most windows and skylights. They are most effective when used in conjunction with low-E coatings. For these reasons, some manufacturers have made gas fills standard in their low-E windows and skylights.

The insulating value of an entire window can be very different from that of the glazing alone. The whole-window U-factor includes the effects of the glazing, the frame, and, if present, the insulating glass spacer. (The spacer is the component in a window that separates glazing panes. It often reduces the insulating value at the glazing edges.)

Since a single-pane window with a metal frame has about the same overall Ufactor as a single glass pane alone, frame and glazing edge effects were not of great concern before multiple-pane, low-E, and gas-filled windows and skylights were widely used. With the recent expansion of thermally improved glazing options offered by manufacturers, frame and spacer properties now can have a more pro- nounced influence on the U-factors of windows and skylights. As a result, frame and spacer options have also multiplied as manufacturers offer improved designs.

Window frames can be made of aluminum, steel, wood, vinyl, fiberglass, or composites of these materials. Wood, fiberglass, and vinyl frames are better insulators than metal. Some aluminum frames are designed with internal thermal breaks, non-metal components that reduce heat flow through the frame. These thermally broken aluminum frames can resist heat flow considerably better than aluminum frames without thermal breaks. Composite frames may use two or more materials (e.g. aluminum-clad wood, vinyl-clad wood) to optimize their design and performance, and typically have insulating values intermediate between those of the materials comprising them. Frame geometry, as well as material type, also strongly influences thermal performance properties.

Spacers can be made of aluminum, steel, fiberglass, foam, or combinations of these materials. Spacer thermal perfor-

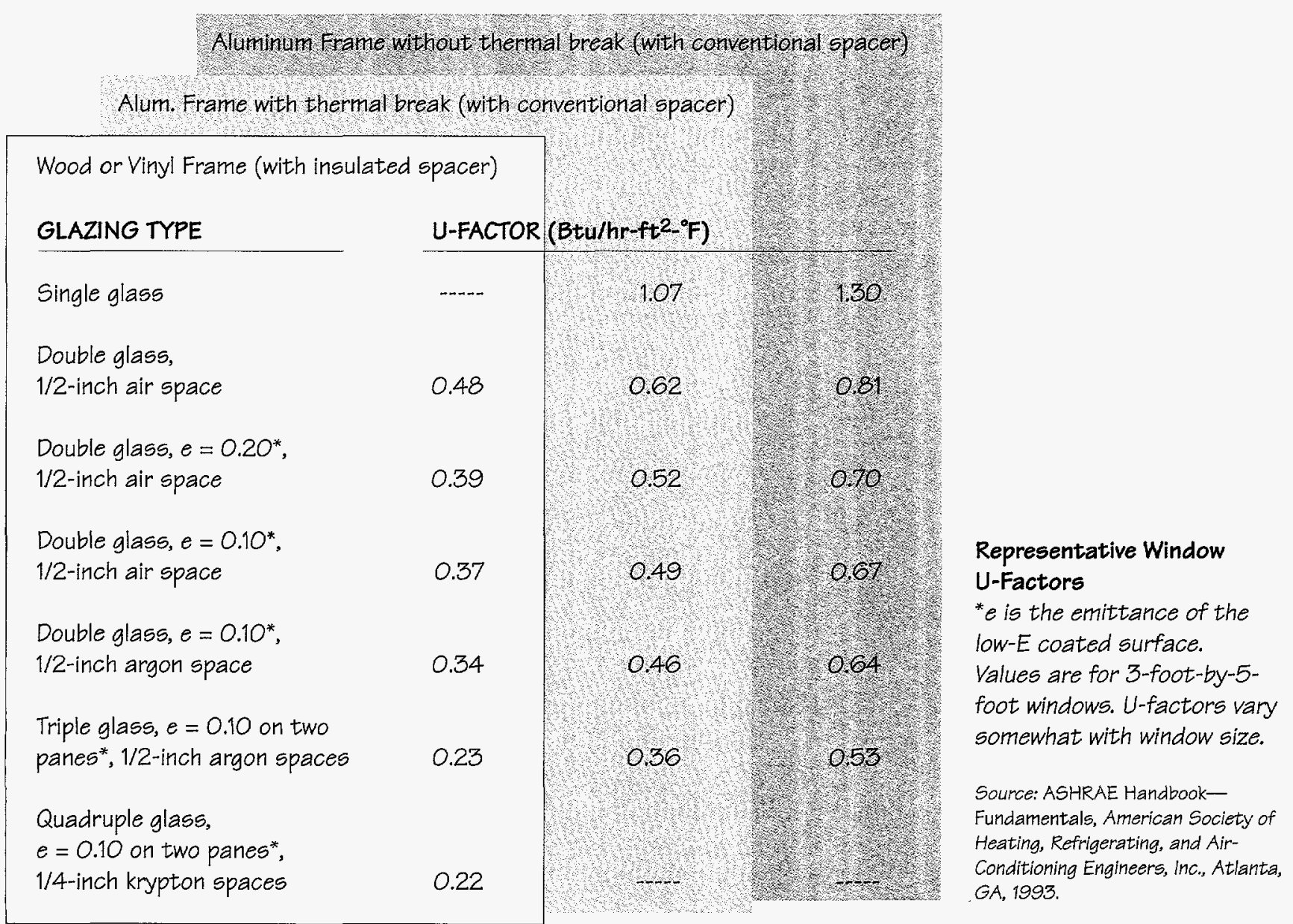


Outdoor air temperature and indoor air relative humidity combinations at which condensation will occur on the center of the glass for single, double, and triple glazings, some with low-E coatings and gas fills.

On or above each curve, the conditions are right for condensation. Below each curve, condensation will not occur on that glazing type as long as the glazing is exposed to room air circulation. Values are based on winter conditions: $70^{\circ} \mathrm{F}$ indoor air temperature, $15 \mathrm{mph}$ outdoor air velocity, and no incident solar radiation.

Source: WINDOW 4.1 (a computer program for calculating the thermal and optical properties of windows), Lawrence Berkeley National Laboratory, Berkeley, CA, 1994.

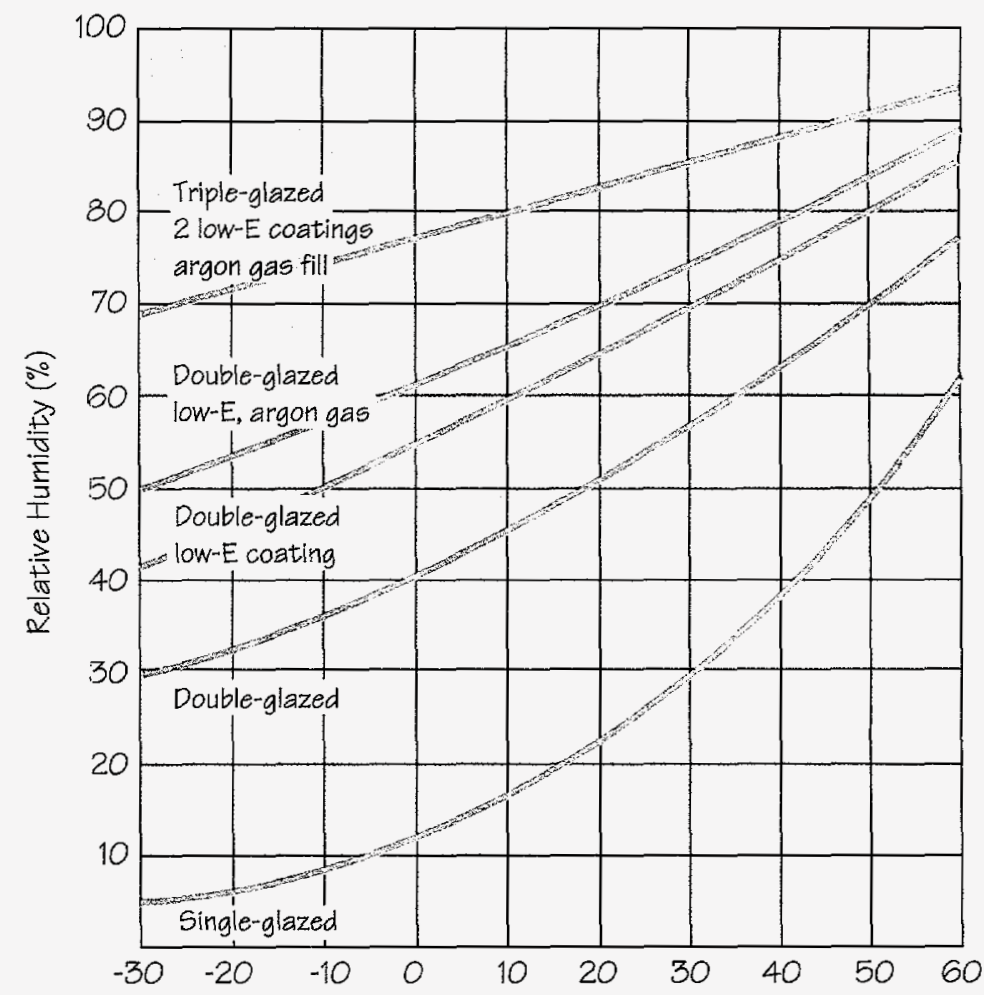

mance is as much a function of geometry as of composition. For example, some well-designed metal spacers insulate almost as well as foam.

The table on page 3 shows representative U-factors for window glazing, frame, and spacer combinations under winter design conditions. Due to their orientation and their greater projected surface areas, domed and other shaped tilted and horizontal skylights have significantly higher $U$-factors than do vertical windows of similar materials and opening sizes.

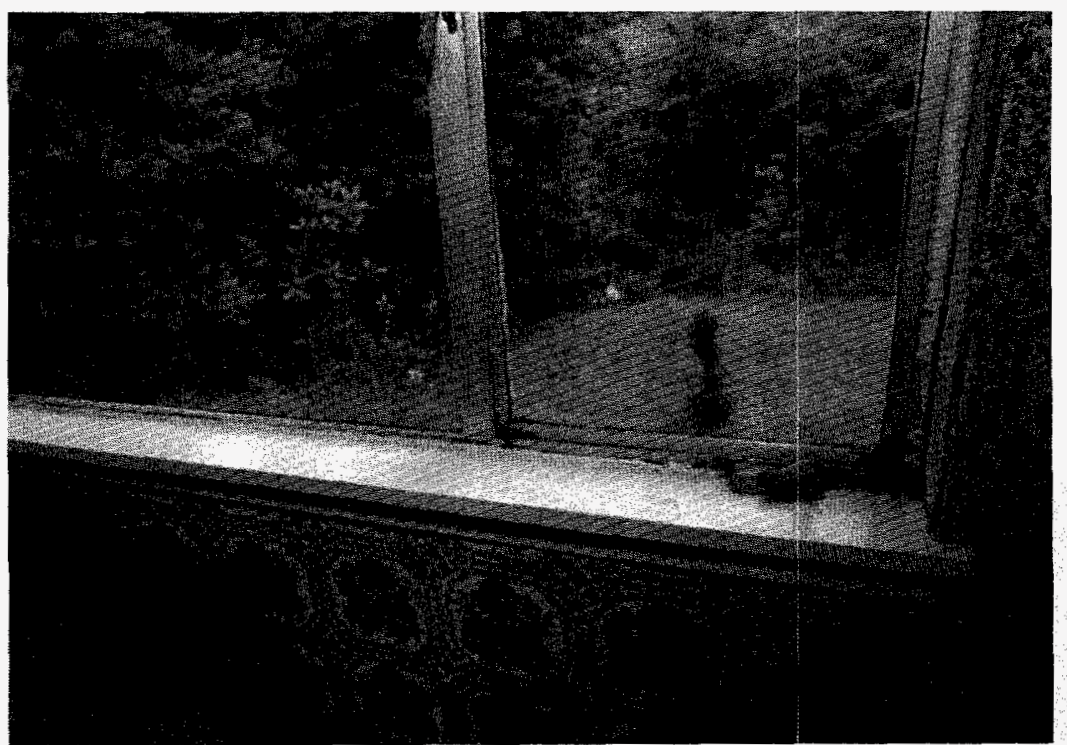

mavering conempent

Air can hold varying amounts of water vapor or moisture. The warmer the air is, the more moisture it can hold. The amount of moisture in the air, expressed as a percentage of the maximum amount the air could hold at a given temperature, is called its relative humidity. For health and comfort, indoor air should contain some moisture. The relative humidity should generally be between $30 \%$ and $40 \%$ at normal room temperature.

The relative humidity of air can be increased by adding more moisture or by reducing the temperature. When the relative humidity reaches $100 \%$, the air can hold no more moisture, and water begins to condense from it. The temperature at which this condensation occurs is called the dew point temperature of the air. When moist air comes in contact with a cold surface in a home, it may be cooled to its dew point temperature, resulting in condensation on the surface.

Single-glazed windows characteristically suffer from water condensation problems and the formation of frost on the inside surface of the glass in winter. 
Windows don't cause condensation, but historically they have been the first and most obvious place it occurs. This is because windows generally have lower thermal resistances than insulated walls, ceilings, and floors. As a result, their inside temperatures are usually lower than those of other surfaces in a home during cold weather. If the air in a home is humid enough, water will condense from it when it is cooled at a window surface.

Condensation is most often thought of as a cold climate winter problem. However, in hot, humid weather, moisture can condense on the outside surface of a poorly insulated window in an air-conditioned building.

Left unchecked, condensation can damage window frames, sills, and interior shades. Water can deteriorate the surrounding paint, wallpaper, plasterboard, and furnishings. In severe cases, it can seep into adjoining walls, causing damage to the insulation and framing.

The indoor air coming in contact with energy-efficient windows is less likely to be cooled to its dew point temperature because the inside surface temperatures remain higher during cold weather than do those of windows with single glazing, traditional metal spacers, and metal frames.

The figure on page 4 illustrates conditions under which condensation will form on the center of the glass of five glazing types with widely varied $U$-factors. The graph shows clearly that the risk of condensation at the center of the glass is reduced as the insulating value of the glass increases. Even at an outdoor air temperature of $-30^{\circ} \mathrm{F}$, the indoor air relative humidity must be nearly $70 \%$ before condensation will form on the triple glazing with two low-E coatings and a gas fill. On the other hand, at an outdoor temperature of $10^{\circ} \mathrm{F}$, condensation will form on the single glazing at an indoor relative humidity of only $18 \%$.

Condensation is even more likely to occur at window spacers and frames, which are usually less insulating than the corresponding glazings. With so many insulating glazing types available, efforts to prevent condensation have shifted toward the development of better insulating spacers and frames.
Reconmendatons for Selechng Wricon U-Faotors

When shopping for windows and skylights, pay close attention to whether the $\mathrm{U}$-factor listed by the manufacturer applies to the glazing only or to the entire unit. If it is for the glazing only, the overall U-factor may be considerably higher because of the frame and spacer effects. These effects increase with decreasing total window area. Compare different window types or makes by their total Ufactors, which are best obtained from NFRC labels. (See Window Energy Rating and Labeling, page 10.) New window energy ratings and the RESFEN computer program can be used to estimate the relative energy usage associated with a particular window type and U-factor.

Avoid aluminum-frame windows without thermal breaks if possible. Even in milder climates, these windows tend to have low inside surface temperatures during the heating season, giving rise to condensation problems. Aluminum-frame windows with properly designed thermal breaks can be used in moderate climates. Wood, vinyl, and fiberglass are the best frame materials for maximum insulating value.

Single-pane windows are impractical in heating-dominated climates. In these regions, multiple-pane, low-E, and gasfilled window configurations are advisable. In most climates, glazings with lowE coatings and gas fills will be a choice that provides significant energy savings in a cost-effective product. Low-E and gas fills have now become a common option for many manufacturers, which reduces their added cost. The resultant total window U-factor should be 0.5 or lower and preferably below 0.4 for maximum energy savings. Consumers should select windows with long warranty periods, which indicate sound window design and construction, and a reduced probability of insulating glass seal failure or gas leakage, which would reduce performance. Remember that lower window and skylight U-factors mean less energy consumption, lower utility bills, and greater comfort in the living space.

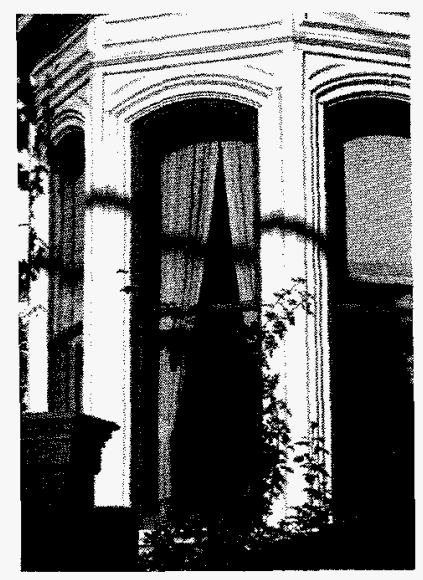


Daily total solar heat gain through 1/8-inch clear single glass for various window orientations on very clear days at $40^{\circ} \mathrm{N}$ latitude (for example, Columbus, Ohio, and Boulder, Colorado).

Source: ASHRAE HandbookFundamentals, American Society of Heating, Refrigerating, and AirConditioning Engineers, Inc., Atlanta, GA, 1993.
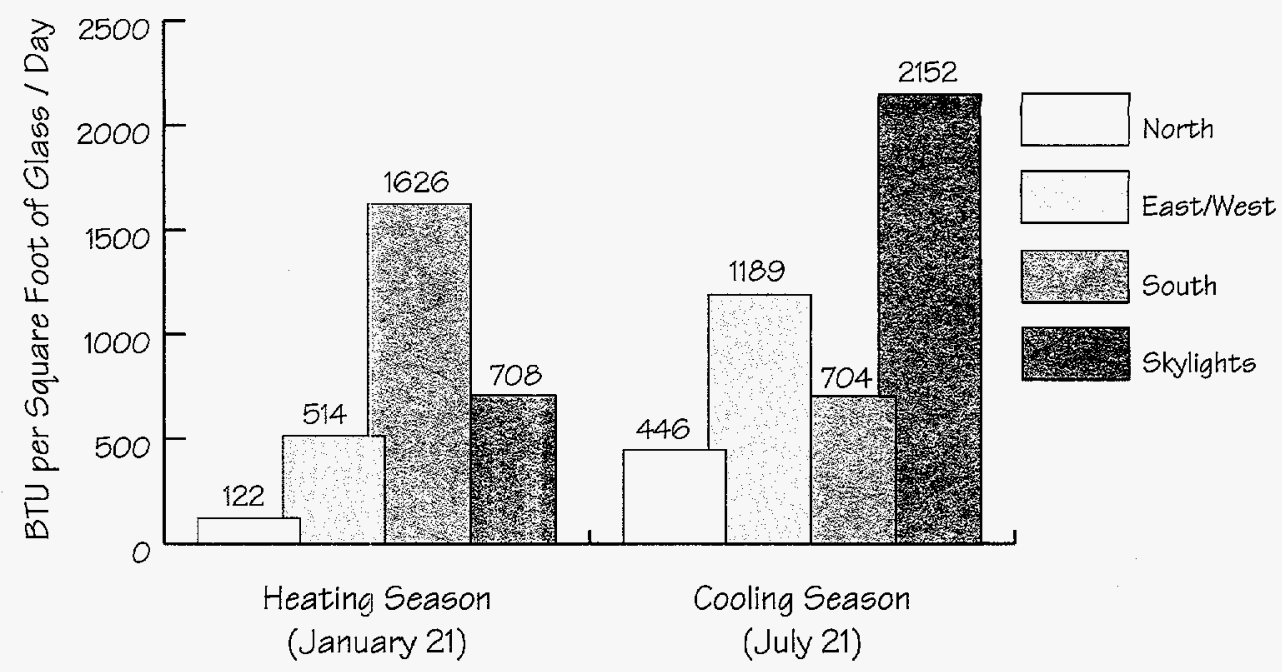

\section{Solar Coner}

Solar transmission through windows and skylights can provide free heating during the heating season, but it can cause a home to overheat during the cooling season. Depending upon orientation, shading and climate, solar-induced cooling costs can be greater than heating benefits in many regions of the United States. In fact, solar transmission through windows and skylights may account for $30 \%$ or more of the cooling requirements in a residence in some climates.

Because the sun's position in the sky changes throughout the day and from one season to another, window orientation has a strong bearing on solar heat gain. The figure above shows the solar heat gain through 1/8-inch clear single glass for various window orientations on very clear days in the heating and cooling seasons at

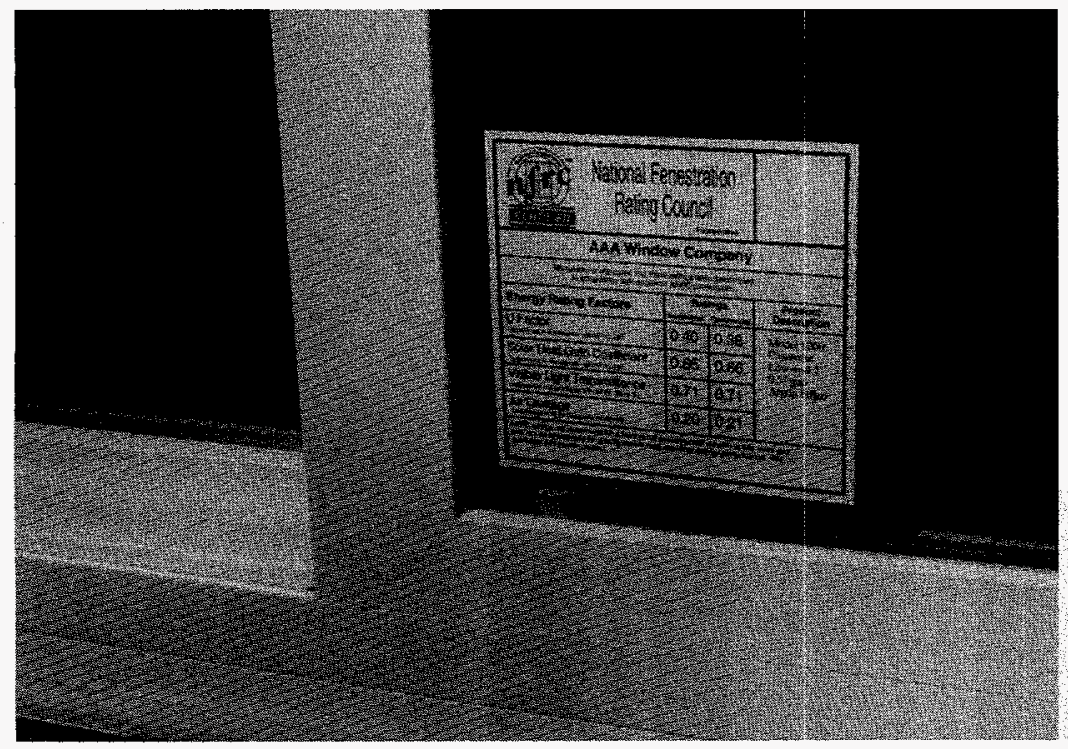

$40^{\circ} \mathrm{N}$ latitude. South-facing windows allow the greatest and potentially most beneficial solar heat gain during the heating season, while admitting relatively little of the solar heat that contributes to cooling requirements during the cooling season. The reverse is true for skylights and east- and west-facing windows. North exposures transmit only minimal solar heat at any time. The ultimate importance of these climatic and orientation effects will depend on the type of glazing under consideration.

The Solar Heat Gain Coefficient (SHGC) is a measure of the rate of solar heat flowing through a window or skylight. (A Shading Coefficient (SC) is the previous standard indicator of a window's shading ability and for simple glazings is approximately equal to the solar heat gain coefficient multiplied by 1.15 .) Solar heat gain coefficients allow consumers to compare the solar heat gain properties of different windows and skylights. The solar heat gain coefficient accounts for both the transmissive glazing element, as well as the opaque frame and sash.

Additional glazing layers provide more barriers to solar radiation, thus reducing the solar heat gain coefficient of a window. Tinted glazings, such as bronze and green, provide lower solar heat gain coef-

The NFRC label provides useful information-such as the window's U-Factor, Solar Heat Gain Coefficient, Visible Light Transmittance, and Air Leakage rating to help you choose wisely. 
ficients than does clear glass. Low-E coatings can be engineered to reduce window solar heat gain coefficients by rejecting more of the incident solar radiation. Spectrally selective glazings, including some low-E coated glazings with low solar heat gain coefficients and new light blue and light blue-green tinted glazings, block out much of the sun's heat while maintaining higher visible transmittances and more neutral colors than more heavily tinted bronze and grey glazings. Hightransmittance, low-E coatings, used in conjunction with a tinted outer glass layer, also reduce solar heat gain by preventing the absorbed heat from reaching the interi- or space. Mirror-like reflective glazings are commonly used in office buildings, but only occasionally chosen for residences. While they may have very low solar heat gain coefficients, they block so much of the light and view that they are not normally desirable in homes.

The table below shows representative solar heat gain coefficients and visible transmittances for glazings with typical wood or vinyl frames and aluminum spacers. Aluminum-frame windows of comparable size and glazing type generally have slightly higher solar heat gain coefficients because of their thinner frames and greater glazing areas.

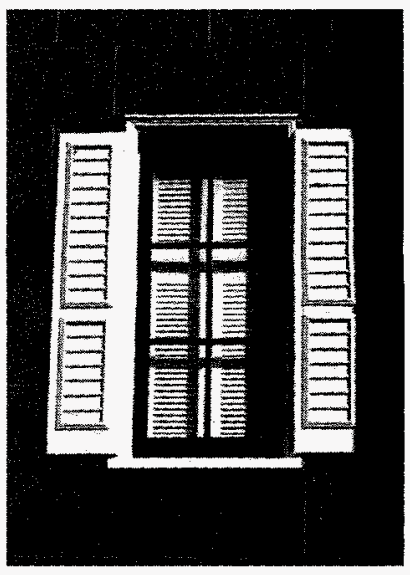

Solar Heat Gain Coefficient

\begin{tabular}{|c|c|c|c|c|}
\hline \multicolumn{3}{|c|}{ Visible Transmittance } & \multirow[b]{2}{*}{$\begin{array}{l}\text { glass } \\
\text { only }\end{array}$} & \multirow[b]{2}{*}{$\begin{array}{l}\text { total } \\
\text { window }\end{array}$} \\
\hline GLAZING TYPE & $\begin{array}{l}\text { glass } \\
\text { only }\end{array}$ & $\begin{array}{l}\text { total } \\
\text { window }\end{array}$ & & \\
\hline Single glass, clear & 0.90 & 0.66 & 0.86 & 0.66 \\
\hline Single glass, bronze tint & 0.68 & 0.50 & 0.73 & 0.56 \\
\hline Single glass, green tint & 0.82 & 0.60 & 0.71 & 0.55 \\
\hline $\begin{array}{l}\text { Single glass, clear, solar control } \\
\text { retrofit film }\end{array}$ & 0.25 & 0.18 & 0.40 & 0.33 \\
\hline Double glass, clear, 1/2-inch air space & 0.81 & 0.59 & 0.76 & 0.59 \\
\hline $\begin{array}{l}\text { Double glass,bronze tint } \\
\text { outer pane, } 1 / 2 \text {-inch air space }\end{array}$ & 0.62 & 0.45 & 0.62 & 0.49 \\
\hline $\begin{array}{l}\text { Double glass, green tint } \\
\text { outer pane, } 1 / 2 \text {-inch air space }\end{array}$ & 0.75 & 0.54 & 0.60 & 0.47 \\
\hline $\begin{array}{l}\text { Double glass, clear, } \\
e=0.20^{*}, 1 / 2 \text {-inch air space }\end{array}$ & 0.76 & 0.55 & 0.65 & 0.51 \\
\hline $\begin{array}{l}\text { Double glass, } \\
\text { "Southern" low-E, e=0.08*, } \\
\text { on tint, } 1 / 2 \text { inch air space }\end{array}$ & 0.45 & 0.33 & 0.35 & 0.29 \\
\hline $\begin{array}{c}\text { Double glass, spectrally selective, } \\
e=0.04^{*}, 1 / 2 \text {-inch argon space }\end{array}$ & 0.72 & 0.52 & 0.40 & 0.33 \\
\hline $\begin{array}{l}\text { Triple glass, clear, } \\
e=0.08 \text { on two panes* } \\
3 / 8 \text { to } 1 / 2 \text {-inch air or argon spaces }\end{array}$ & 0.68 & 0.50 & 0.49 & 0.39 \\
\hline
\end{tabular}

Representative Window Solar Heat Gain Coefficients and Visible Transmittances

Values are for a 3-foot-by5-foot horizontal slider window with wood or vinyl frames and aluminum spacers. Solar heat gain coefficients vary somewhat with window size.

${ }^{*} e$ is the emittance of the lowE coated surface; emittance will vary slightly with specific products.

Source: WINDOW 4.1 (a computer program for calculating the thermal and optical properties of windows), Lawrence Berkeley National Laboratory, Berkeley, CA, 1994. 


\section{Efrravioler Pronesilon}

Ultraviolet radiation is the main component of sunlight that can fade and damage drapes, carpets, furniture, and paintings when transmitted through windows and skylights. Efforts to produce window glazings that transmit less ultraviolet energy have met with some success. In general, windows and skylights with plastic glazing layers or low-E coatings reduce ultraviolet transmission. Even without any ultraviolet radiation, sunlight can still cause fading of fabrics and other furnishings.

\section{Recommand Solar Control}

Consumers should consider two aspects of window selection to control solar gain-the selection of the window itself and the choice of interior or exterior shading devices. Traditional windows with clear glass required the use of shading devices to obtain adequate performance, especially when the orientation admitted substantial sunlight in summer. However, modern high-performance windows can do such a good job of controlling sunlight that the importance of these shading systems is reduced.

Window Solar Heat Gain Coefficients should ideally be selected according to orientation, but it may not always be practical to do so. If south exposures are to admit beneficial solar heat during the heating season, their Solar Heat Gain Coefficients should be high. These high coefficients will not usually result in overheating problems during the cooling season because of the lower solar radia-

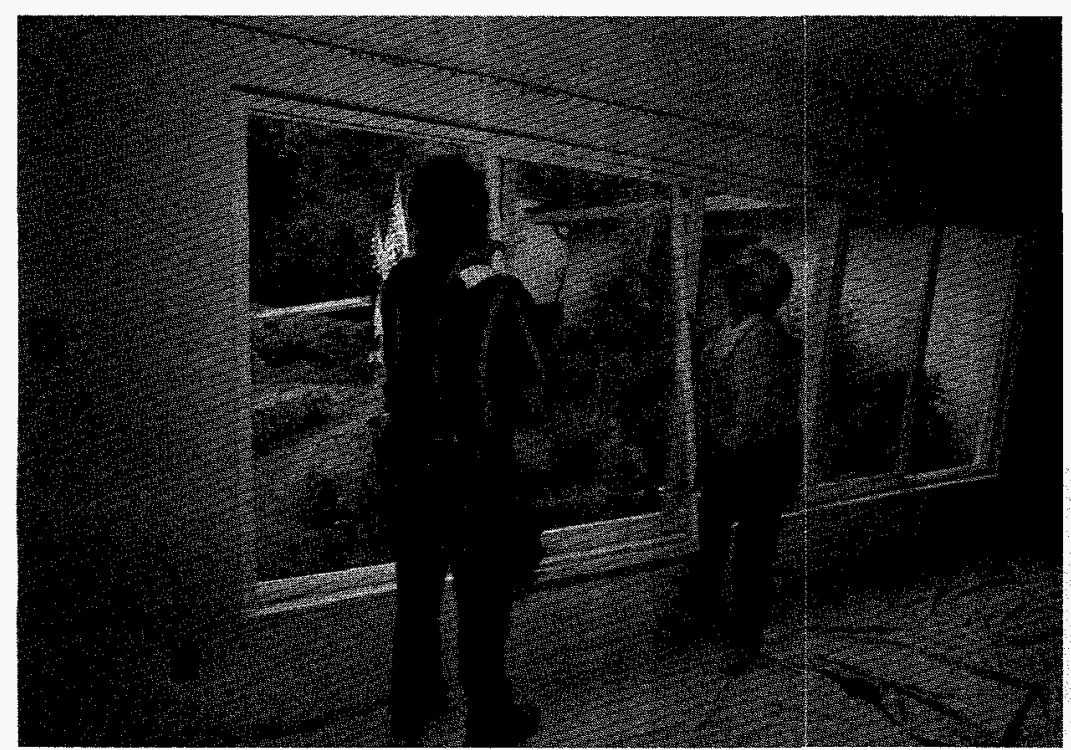

tion levels at that time on south-facing windows, especially those with adequate roof overhangs.

Skylights and east- and west-oriented windows may warrant lower solar heat gain coefficients since they transmit the most solar heat during cooling periods. In most climates, there is not much point in spending more money to obtain lower solar heat gain coefficients for north-facing windows.

In hot, sunny climates, select windows with spectrally selective glazings to provide low solar heat gain coefficients without loss of light. Darker tinted glazings also provide lower solar heat gain coefficients, but they will yield somewhat decreased outdoor visibility, particularly at night. Where glare is a concern, this effect may be desired, but under other conditions it may not. In climates where cooling loads are large, look for windows with a SHGC of 0.4 or less. To maintain good light transmittance and visibility, select windows whose glazings have visible transmittance of 0.6 or higher.

In some hot climates, where winters are mild, it might seem reasonable to select a single-glazed window with a low Solar Heat Gain Coefficient rather than a more typical double glazing. However, single glazings have a more limited range of solar control (even if laminated glass and glue-on plastic films are considered), so a double-glazed window with appropriate glazing choice as noted above, may be the best overall solution, even in hot climates.

Exterior or interior shading devicessuch as awnings, louvered screens, sunscreens, venetian blinds, roller shades, and drapes-are essential for shading clear glass, and can complement and enhance the performance of windows with low Solar Heat Gain Coefficients. One advantage of many shading devices is that they can be adjusted to vary solar heat transmission with the time of day and season. But windows with "built-in" lower Solar Heat Gain Coefficients pro-

\footnotetext{
Commercially available windows must meet numerous standards and building regulations addressing condensation resistance, sound control, maintenance requirements, and overall durability of the unit.
} 
vide better visibility and require less management and maintenance in today's busy households.

Exterior shading devices are more effective than interior devices in reducing solar heat gain because they block radiation before it passes through a window. Light-colored shades are preferable to dark ones because they reflect more, and absorb less, radiation. Horizontally oriented adjustable shading devices are appropriate for south-facing windows, while vertically oriented adjustable devices are more effective for shading windows on east and west orientations.

$\begin{array}{lc}\text { Sash Type } & \begin{array}{c}\text { Effective } \\ \text { Open Area* }\end{array} \\ & \\ & \\ \text { Casement } & 90 \% \\ \text { Awning } & 95 \% \\ \text { Hopper } & 45 \% \\ \text { Horizontal sliding } & 45 \% \\ \text { Single-hung } & 45 \% \\ \text { Double-hung } & 45 \% \\ & \end{array}$

Representative Window Ventilation Areas *Effects of window screens are not included.

Source: R.K. Vieira and K.G. Sheinkopf, EnergyEfficient Florida Home Building, FSEC-GP-3388. Florida Solar Energy Center, Cape Canaveral, FL, 1988.

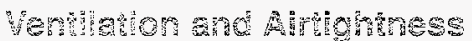

Airflow through and around windows occurs by design as ventilation and inadvertently as infiltration. The use of windows for natural ventilation is as old as architecture itself. Opening windows, particularly on opposite sides of a living space, can cool a home for free. The sash type of a window influences the ventilation airflow rate through the window relative to its size. Some common sash types and their effective open areas for ventilation purposes are shown in the table above. Casement windows are especially effective for ventilation because they tend to direct the greatest airflow into the living space when fully open.

Infiltration is the uncontrolled leakage of air into a building from the exterior through joints and cracks around window and skylight frames, sash, and glazings. This leakage can account for up to $10 \%$ of the energy usage in a home. The airtightness of a window depends on both the characteristics of the window-such as sash type and overall quality of window construction - and the quality of the installation. Operable windows with compressing seals are generally more airtight than purely sliding seals, because of the way the sash element seals against the framing.

An air leakage rating is a standardized measure of the rate of infiltration through a window or skylight under specific environmental conditions. Air leakage ratings allow consumers to compare the airtightness of different windows and skylights as manufactured products; they do not account for leakage between the installed product and the wall or roof. Lower air leakage ratings indicate greater airtightness.

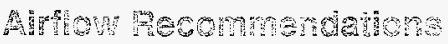

In milder climates, or in spring and fall in more severe climates, operable windows can provide ventilation, improve comfort, and reduce the need for air conditioning. Operable windows are often specified to meet building code requirements for emergency egress. Although operable windows are sometimes useful in household areas with high moisture production, such as bathrooms, kitchens, and laundry rooms, exhaust fans provide more reliable control throughout the year.

Select windows with air leakage ratings that meet or exceed standard industry requirements of $0.37 \mathrm{cfm} / \mathrm{ft}^{2}$ to minimize discomfort from uncontrolled infiltration. Select windows with even lower values for particularly windy sites or harsh climates. Check the seals between window components for airtightness. To minimize infiltration around installed windows, follow the manufacturer's installation procedures carefully and seal and caulk joints and cracks.

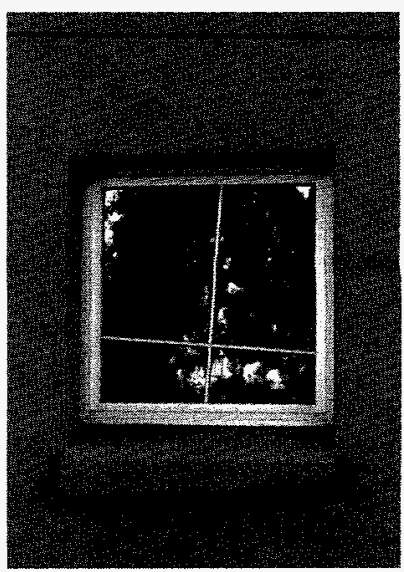




\section{Window Energy Rating and Labeling}

M

any windows, skylights, and

glazed doors now bear energy

being placed on household appliances, to assist consumers in selecting energy-efficient products. The labels have been developed by a non-profit group, the National Fenestration Rating Council (NFRC). The following interview with NFRC staff, provides horneowners, architects, and builders with some important information on these new window energy ratings.

Why are energy ratings or labels important for windows and skylights?

Fenestration-windows, skylights, and glazed doors — can account for over $25 \%$ of the heating and cooling energy bills in a typical home.

Designers, builders, and homeowners have never had a tool for determining or comparing the energy performances of fenestration products to assist them in their purchase decisions. Many manufacturers offer a variety of energy-efficient products, but have not been able to demonstrate their superiority through comparable performance ratings.

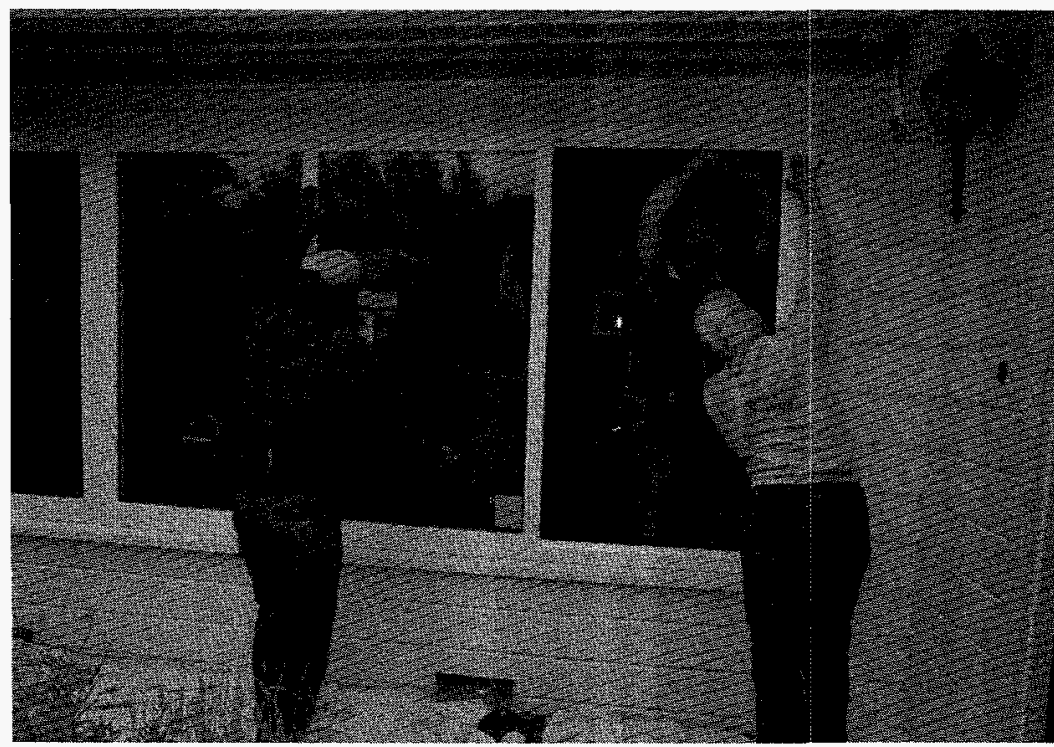

How will designers and homeowners use these energy labels?

Energy labels will show a variety of product performance attributes, enabling designers to compare and select products directly, based on each project's specific energy performance needs. Until now, designers have had to spend too much time trying to understand a mixed bag of rating techniques, test methods, and performance claims. A nationwide system for rating whole-product energy performance will not only give designers the energy information they seek, but will also permit direct product comparisons.

Homeowners have faced a similar dilemma. When selecting fenestration products for a remodeling project or new construction, homeowners have had no way to compare the energy performances of two products directly. This difficulty has been compounded by the different energy rating techniques employed by the various industry segments. Window energy labels will enable consumers to compare products directly, regardless of glazing and frame type.

How will the energy ratings be determined?

The energy ratings are determined using advanced computer tools developed in the United States and Canada, combined with standardized product performance testing. The WINDOW 4.1 program, developed at Lawrence Berkeley National

In evaluating the cost of new or replacement window units, the aesthetic, functional, and energy performance characteristics come together. To make a better decision, it is useful to think of the life-cycle cost of the unit. 


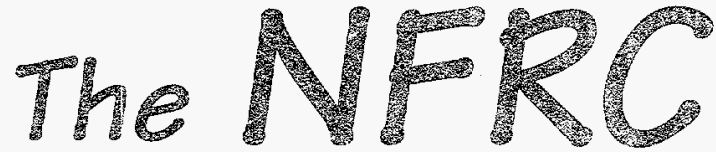

When shopping for windows, look for the
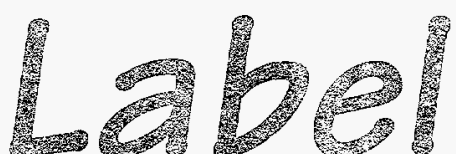

1300 Spring Street, Suite 120 Silver Spring, MD 20910

Telephone: (301) 589-6372

Fax: (301) 589-0854

e-mail: NFRCUSA@aol.com

Web: http://wwwintr.org

National Fenestration Rating Council

(NFRC) label as your guide to buying energy-efficient windows. The NFRC is a non-profit public/private collaboration that provides contractors and homeowners with standardized, unbiased methods of comparing various brands and types of windows.

Below is an example of an NFRC label. All the parts of the label are described, but the U-factor and Solar Heat Gain Coefficient, which rate the efficiency of the entire window (glass and frame), are the most important in helping choose the best window for your purposes. All labels have U-factors; Solar Heat Gain Coefficients and Visible Light Transmittance are now being added. Air leakage ratings and annual heating and cooling factors will be added in the near future.

The U-factor is a measure of heat transmission due to a temperature difference. The smaller the U-factor, the less heat is trans mitted.

The Solar Heat Gain Coefficient is a measure of the rate of solar heat flow through the window.

The Visible Light Transmittance value is a measure of the fraction of visible light that passes through the window.
The NFRC insignia is your assurance that this window has been independently rated.
This box contains the name of the Independent Certification and Inspection Agency (A) selected by the window manufacturer.
Name of the window manufacturer.

Description of the particular product to which this label is attached.

Since ratings can vary depending on the typical size of windows in different building types, values are given for both residential and commercial applications.

The Air Leakage rating is a measure of the rate of infiltration through this particular window. 
Laboratory, is one of the fundamental building blocks of the rating system. This program and the FRAME program are used to calculate the $U_{-}$ factors and Solar Heat Gain

Coefficients of windows. Air leakage and other energy performance attributes are also being rated. Soon, homeowners will see two new ratings, the Fenestration Heating Rating (FHR) and Fenestration Cooling Rating (FCR), which provide a comparative index of heating and cooling season energy use. The RESFEN program, developed at Berkeley Lab, can also be used to estimate the annual energy consumption and costs associated with a particular window type and orientation in a specific geographic location, based on local utility costs.

Who is responsible for implementing the window energy performance rating and labeling program?

The National Fenestration Rating Council has developed and is implementing this rating and labeling system. NFRC is a non-profit coalition of manufacturers, builders, state and federal energy officials, private and government laboratories, utilities, consumers, and others working together to develop a nationwide energy performance rating system that is fair, accurate, and credible. As
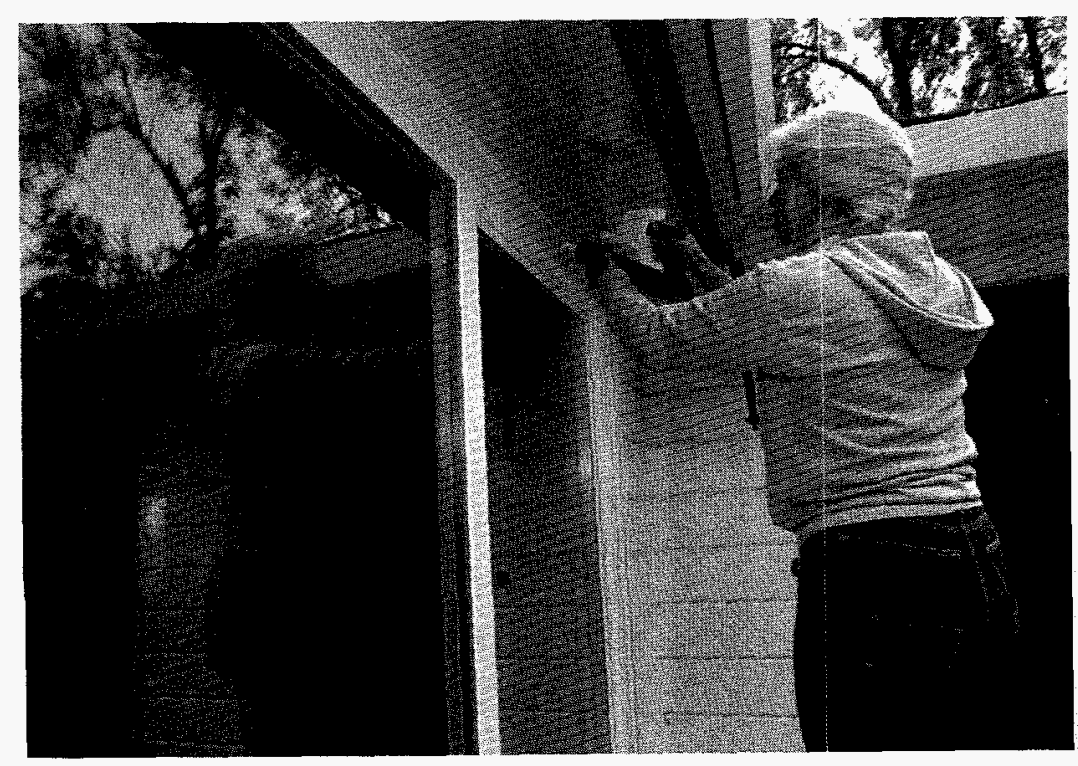

a result of this effort, consumers across the country now have energy rating labels on windows, skylights, and glazed doors analogous to those on automobiles, appliances, and insulation.

\section{Are these computer tools available to the public?}

Yes. These computer tools are available through the National Fenestration Rating Council for use by building energy professionals, engineers, architects, and others. NFRC also provides detailed training for manufacturers and design professionals in the proper use of these window-related computer tools. For more information on these computer programs, contact:

\author{
National Fenestration Rating Council \\ 1300 Spring Street, Suite 120 \\ Silver Spring, MD 20910 \\ Telephone: (301) 589-6372 \\ Fax: (301) 589-0854 \\ e-mail: NFRCUSA@aol.com \\ Web: http://www.nfrc.org
}

Where might I see NFRC labels referenced or used?

Several state building codes and other organizations with an interest in promoting energy efficiency, such as utilities, are already referencing NFRC ratings. The ratings are a prerequisite for some special programs, such as low-interest financing to purchase energy-efficient windows. Look for labels on products displayed in your local building materials supply store or window store. NFRC ratings are listed in the product literature, available from many window manufacturers, architects, or builders.
Choosing a better-performing window to save on fuel costs will also improve comfort and performance in other areas. When shopping for windows, look for the NFRC Label as your guide. 


\section{For Design, Specification, and Installation}

his checklist guides homeowners, architects, and builders in selecting residential windows and skylights. Selecting the right window can be difficult because of the many factors involved and the great variations in climate, utility costs, and occupant needs. Check boxes are provided for marking entries during the selection or design process. Note that each entry below does not apply to all circumstances and that some general guidance may appear to be contradictory because all of the detailed conditions cannot be specified. Users should mark the items that apply to their particular needs. Other local sources of information for window selection are utilities, state and local building code officials, design professionals, and building materials suppliers.

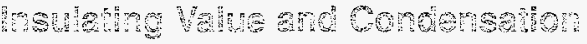 Resishane?}

$\square$ Look for NFRC U-factor ratings and labels to guide window selection.

$\square$ Select double-pane windows in all climates where heating is needed. Select double- or triple-pane windows with low-E coatings and gas fills in cold climates to reduce heat losses and condensation.

$\square$ To reduce frame and edge heat losses and condensation in all climates where heating is needed, select windows with wood, vinyl, fiberglass, or properly designed, thermally broken aluminum frames.

Use heavy drapes, thermal shades, or thermal shutters to provide additional window insulation in cold climates.

\section{Soler Convel and Uhravidet promentor}

- Look for NFRC Solar Heat Gain Coefficient ratings and labels to guide window selection.

Select windows with spectrally selective glazings (special tints or modified low-E coatings) to reduce solar heat gains (SHGC less than 0.4) while maintaining high visible transmittance (glass transmittance greater than 0.6).

$\square$ Select tinted windows to reduce solar heat gains and control glare by lowering visible transmittance.

$\square$ Select special glazings (with plastic layers or low-E coatings) to reduce ultraviolet transmission in rooms with materials subject to fading. (If this is a critical concern, consult expert assistance.)
If shading devices are to be used to supplement the use of high-performance windows, consider the following points:

$\square$ Select light-colored shading devices to minimize solar heat gains.

$\square$ Select exterior shading devices to minimize the inward flow of absorbed solar heat.

$\square$ Select interior shading devices to reduce solar heat gains while providing for privacy and aesthetics, or when exterior shading devices cannot be used.

$\square$ Select horizontally oriented shading devices for south-facing windows and vertically oriented shading devices for east- and west-facing windows.

$\square$ Specify overhangs, exterior awnings, or the planting of deciduous trees and shrubs to shade south-facing windows during the summer while allowing beneficial solar heat gains during the winter.

\section{Darlohis and vism}

$\square$ Look for NFRC Visible Light

Transmittance ratings and labels to guide window selection.

$\square$ Select window size, location, and glass type to provide adequate daylight levels in each space.

Select windows with high visible transmittances (greater than 50\%) to maximize outward visibility.

$\square$ Specify window sizes and positions in walls to take advantage of desirable views.

$\square$ Position windows away from bright external surfaces that create glare.

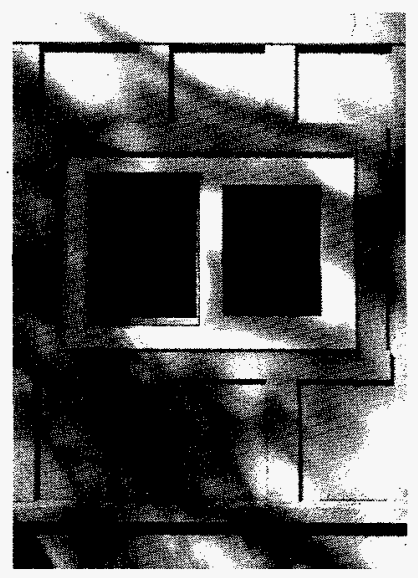




\section{Yonthaton and Anming}

$\square$ Select operable windows for rooms requiring substantial ventilation during mild weather and to meet building code egress requirements.

$\square$ Select casement or awning windows to maximize effective ventilation area.

$\square$ Select awning windows to better exclude precipitation while ventilating.

$\checkmark$ Position operable windows in opposite walls of living spaces to maximize crossventilation.

$\square$ Select fixed windows or windows with compression seals to minimize infiltration.

$\square$ Select windows and skylights with continuous edge seals to minimize infiltration.

$\square$ Seal and caulk around window and skylight frames and sash to reduce infiltration. Follow the manufacturer's installation instructions.

\section{Sonnd Contre!}

$\square$ Position windows away from external sources of extreme noise.

$\square$ Select double- or triple-pane windows with panes of unequal thickness, laminated glass, or gas fills to minimize noise from the exterior.

\section{Privery, Saren, and security}

$\square$ Select interior shading devices that obscure direct view for additional privacy.

$\square$ Check building codes on fire, wind-loading, and seismic safety before selecting and positioning windows and skylights.

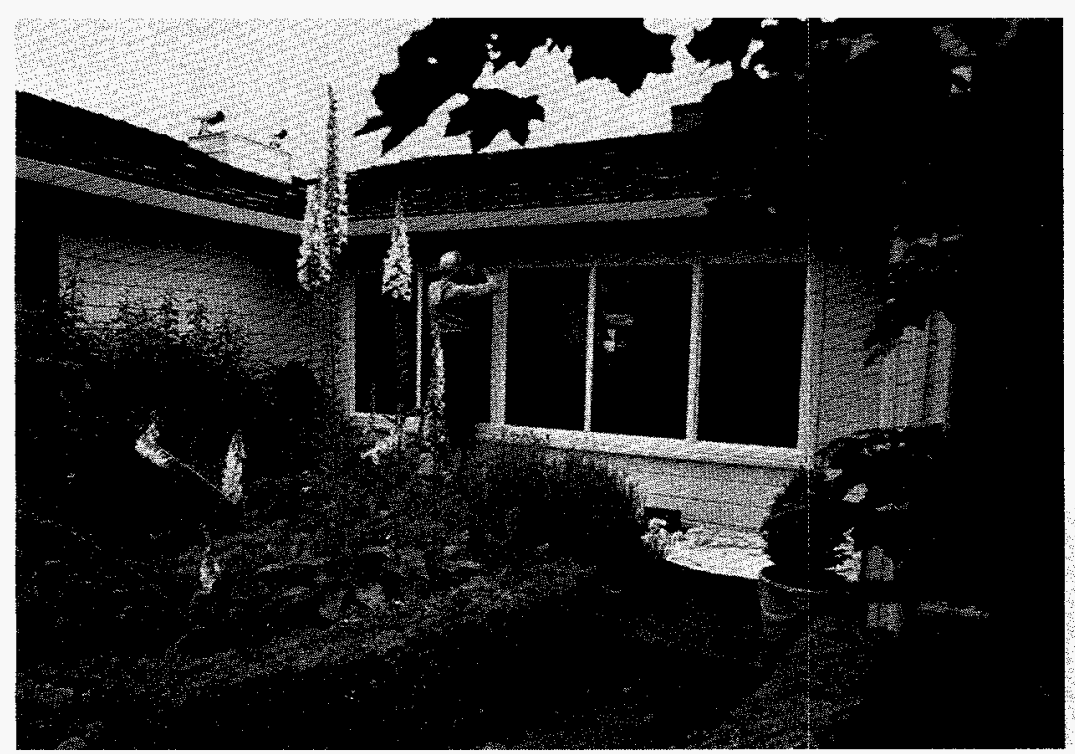

Select laminated glass or tempered glass with screens for skylights and for windows near doors or close to the floor.

$\square$ Select windows with locks or latches that can be easily opened from the interior but cannot be opened from the exterior.

\section{Mintenance, Durabilly, and} Iำexime

$\square$ Check warranties for indication of durability and lifetime before selecting windows and skylights.

$\square$ Check the quality of window construction.

$\square$ Use protective paints, stains, or sealants on wood window and skylight frames or select clad wood products.

$\square$ Follow the manufacturer's instructions to maintain glazing, sash, frame, and hardware in good repair.

\section{mstallation}

$\square$ Check all applicable building codes before installing windows and skylights.

$\square$ Follow the manufacturer's installation instructions carefully.

\section{Fconomics}

$\square$ Consider the relative effects on utility bills when selecting windows and skylights. Contact the NFRC (see Window Energy Rating and Labeling, page 10) or consult energy specialists or utility representatives for estimates of the energy and cost savings provided by energy-efficient windows and skylights.

$\square$ Consider the effects on the resale value of a home when selecting windows and skylights.

$\square$ Check local, state, and federal energy efficiency programs and utility energy conservation programs for economic incentives for installing energy-efficient windows and skylights.

New materials and improvements to all parts of the window assembly have contributed to their high performance. These double-glazed windows with vinyl frames have a high insulating value. 
Air Leakage Rating: A measure of the rate of infiltration around a window or skylight in the presence of a strong wind. It is expressed in units of cubic feet per minute per square foot $\left(\mathrm{cfm} / \mathrm{ft}^{2}\right)$ of window area or cubic feet per minute per foot $(\mathrm{cfm} / \mathrm{ft})$ of window perimeter length. The lower a window's air leakage rating, the better its airtightness.

Conduction: The flow of heat through a solid material, such as glass or wood, and from one material to another in an assembly, such as a window, through direct contact.

Convection: The flow of heat through a circulating gas or liquid, such as the air in a room or the air or gas between windowpanes.

Fenestration: A window or skylight and its associated interior or exterior elements, such as shades or blinds. The placement of window openings in a building wall is one of the important elements in determining the exterior appearance of a building.

Gas Fill: A gas other than air placed between window or skylight glazing panes to reduce the U-factor by suppressing conduction and convection.

Glazing: The glass or plastic panes in a window or skylight.

Infiltration: The inadvertent flow of air into a building through breaks in the exterior surfaces of the building. It can occur through joints and cracks around window and skylight frames, sash, and glazings.

\section{Low-Emittance (Low-E) Coating:}

Microscopically thin, virtually invisible, metal or metallic oxide layers deposited on a window or skylight glazing surface primarily to reduce the U-factor by suppressing radiative heat flow through the window or skylight.

Radiation: The transfer of heat in the form of electromagnetic waves from one separate surface to another. Energy from the sun reaches the earth by radiation, and a person's body can lose heat to a cold window or skylight surface in a similar way.

$\boldsymbol{R}$-Value: A measure of the resistance of a material or assembly to heat flow. It is the inverse of the $U$-factor $(R=1 / U)$ and is expressed in units of $\mathrm{hr}_{-}-\mathrm{ft}^{2}{ }^{\circ}{ }^{\circ} \mathrm{F} / \mathrm{Btu}$. A high window $\mathrm{R}$-value, has a greater resistance to heat flow and a higher insulating value.

Shading Coefficient (SC): A measure of the ability of a window or skylight to transmit solar heat, relative to that ability for 1/8-inch clear, double-strength, single glass. It is equal to the Solar Heat Gain Coefficient multiplied by 1.15 and is expressed as a number without units between 0 and 1 . A window with a lower Shading Coefficient transmits less solar heat, and provides better shading.

\section{Solar Heat Gain Coefficient (SHGC):}

The fraction of solar radiation admitted through a window or skylight, both directly transmitted, and absorbed and subsequently released inward. The Solar Heat Gain Coefficient has replaced the Shading Coefficient as the standard indicator of a window's shading ability. It is expressed as a number without units between 0 and 1 . A window with a lower Solar Heat Gain Coefficient transmits less solar heat, and provides better shading.

Spectrally Selective Glazing: A specially engineered low-E coated or tinted glazing that blocks out much of the sun's heat while transmitting substantial daylight.

U-Factor (U-Value): A measure of the rate of heat flow through a material or assembly. It is expressed in units of $\mathrm{Btu} / \mathrm{hr}-\mathrm{ft}^{2}{ }_{-}^{\circ} \mathrm{F}$ or $\mathrm{W} / \mathrm{m}^{2}-^{\circ} \mathrm{C}$. Window manufacturers and engineers commonly use the $\mathrm{U}$-factor to describe the rate of non-solar heat loss or gain through a window or skylight. Lower window U-factors have greater resistance to heat flow and better insulating value.

Visible Transmittance: The percentage or fraction of visible light transmitted by a window or skylight.

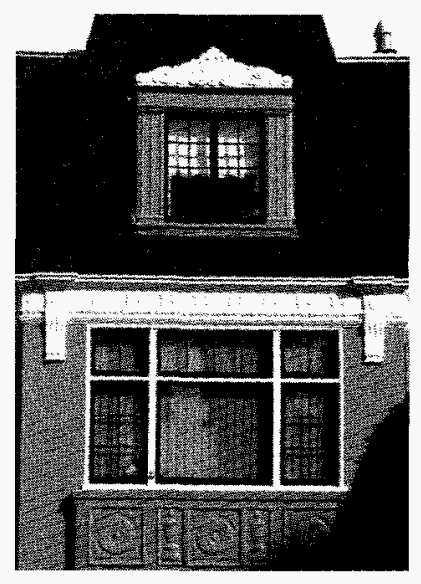




\section{Selecting Windows for Energy Efficiency}

New window technologies have increased energy benefits and comfort, and have provided more practical options for consumers. This

selection guide will help homeowners, architects, and builders take advantage of the expanding window market. The guide contains three sections: an explanation of energy-related window characteristics, a discussion of window energy performance ratings, and a convenient checklist for window selection.

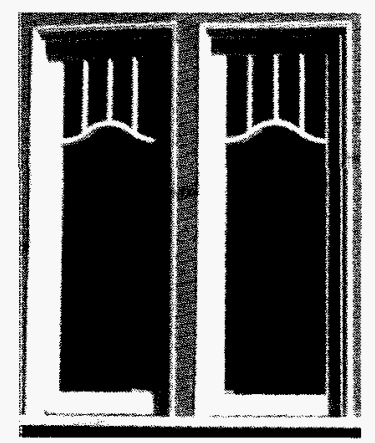

\section{Resources}

In seeking information concerning windows and energy efficiency in general, there are several local resources worth investigating:

- Local utilities

- State or municipal energy agencies

- Regional universities with architecture, construction, or extension programs

- Bookstores

- Product literature at home improvement centers

- Local chapters of the American Institute of Architects

- Local builder's associations

\section{Recommended Web Sites}

Search for specific window and glazing manufacturers and trade organizations by name on the World Wide Web.

American Architectural Manufacturers Association: http://www.AAMAnet.org

American Institute of Architects: http://www.aia.org

American Solar Energy Society: http://www.ases.org/solar

American Society of Heating, Refrigerating \& Air Conditioning Engineers:

http://www.ashrae.org

Home Energy Magazine: http://www.homeenergy.org

National Association of Home Builders: http://www.nahb.com

National Fenestration Rating Council: http://www.nfrc.org

National Wood Window and Door Association: http://www.nwwda.org

National Research Council of Canada:

http://www.cisti.nrc.ca:80/irc/irccontents.html

Natural Resources Canada: http://www.NRCan.gc.ca

Passive Solar Industries Council: http://www.psic.org

U.S. Department of Energy: http://www.eren.doe.gov

\section{Recommended Reading}

Residential Windows: A Guide to New Technologies and Energy Performance, by John Carmody, Stephen Selkowitz, and Lisa Heschong, W.W. Norton \& Company, 1996; http://www.wwnorton.com.
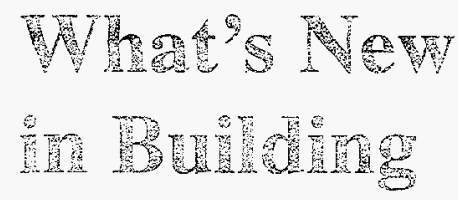

DMP

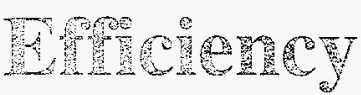

We would like to acknowledge the many window and glazing industry reviewers of this document. We appreciate the time they took to assure the usefulness of this document. Special thanks to V\&W Patio Door \& Window Co., Inc. of Berkeley, California, for making one of their window retrofit installations available for photo illustration of this brochure. This work was supported by the U.S. Department of Energy, Assistant Secretary for Energy Efficiency and Renewable Energy, Office of Building Technology, State and Community Programs, Office of Building Systems.

This document was prepared as an account of work sponsored by the United States Government. While this document is believed to contain correct information, neither the United States Government nor any agency thereof, nor The Regents of the University of California, nor any of their employees, makes any warranty, express or implied, or assumes any legal responsibility for the accuracy, completeness, or usefulness of sibility for the accuracy, completeness, or usefulness
any information, apparatus, product, or process disclosed, or represents that its use would not infringe privately owned rights. Reference herein to any specific commercial product, process, or service by its trade aame, trademark, manufacturer, or otherwise, does not necessarily constitute or imply its endorsement, recommendation, or favoring by the United States Government or any agency thereof, or The Regents of the University of California. The views and opinions of authors expressed herein do not necessarily state or reflect those of the United States Government or any agency thereof, or The Regents of the University of California.

Produced for DOE's Office of Energy Efficiency and Renewable Energy by the Lawrence Berkeley National Laboratory, a DOE national laboratory.

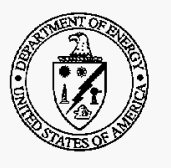

DOE/GO-DE-AC03-76SF00098 PUB-788 May 1997 - 5000

\section{For More Information}

Energy Efficiency and Renewable Energy Clearinghouse P.O. Box 3048

Merrifield, VA 22116

(800) DOE-EREC

(800) 363-3732

(703) 893-0400 fax

http://erecbbs.nciinc.com/

Printed on recycled paper using soy-based inks. 